\title{
Improvement of Apple Quality and Storability by a Combination of Heat Treatment and Controlled Atmosphere Storage
}

\author{
Ibrahim I. Tahir ${ }^{1}$, Eva Johansson, and Marie E. Olsson \\ Faculty of Landscape Planning, Horticulture and Agricultural Sciences, The \\ Swedish University of Agricultural Sciences, P.O. Box 104, Alnarp, 230 53, \\ Sweden
}

Additional index words. apple (Malus domestica), bruising, Penicillium expansum, Colletotrichum gloeosporioides, Pezicula malicorticis, postharvest heating, epicuticular wax

\begin{abstract}
The effects of two nonchemical methods [controlled atmosphere (CA) storage and postharvest heating, alone or combined] on the quality (firmness, taste, color, and skin wax) and storability (losses resulting from bruising and fungal decay) of apples were investigated in a 3-year study. Fruits of two cultivars (cv. Aroma and cv. Ingrid Marie) were mechanically wounded on two opposing sides, inoculated with conidial suspensions of one of three pathogens [Pezicula malicorticis (bull's eye rot), Penicillium expansum (blue mould), and Colletotrichum gloeosporioides (bitter rot)], exposed to $40{ }^{\circ} \mathrm{C}$ for four different exposure periods $(24,48,72$, and $96 \mathrm{~h})$, and stored either in air $\left(21.0 \mathrm{kPa} \mathrm{O}_{2}+\right.$ $0.03 \mathrm{kPa} \mathrm{CO} 2)$ or in CA storage $(2.0 \mathrm{kPa} \mathrm{O}+2.0 \mathrm{kPa} \mathrm{CO})$ for 4 months. Effect of postharvest heating on bruise susceptibility of air- or CA-stored apples was also investigated. Cultivar Aroma apples generally showed higher bruise susceptibility than cv. Ingrid Marie. The sun-exposed side of apples was less sensitive to bruising than the shaded side and red phenotypes of these two cultivars also showed increased resistance to bruising as compared with standard phenotypes. Heat treatment and CA storage, either alone or in combination, decreased bruise occurrence in both cultivars. $P z$. malicorticis was the more aggressive storage pathogen for both apple cultivars followed by $P$. expansum and $C$. gloeosporioides. The highest decay severity occurred in inoculated and nonheat-treated apples stored in air. Heat treatment, especially in combination with CA storage, showed an eradicative effect on the pathogens without any negative effects on apple quality. Heat treatment maintained flesh firmness during storage, reduced ethylene production, and caused clearly visible changes in epicuticular wax structure, resulting in a higher resistance to bruising or to natural and artificial infections with the pathogens. The effective exposure period could be reduced to $24 \mathrm{~h}$, because a combination of heat treatment (at $40^{\circ} \mathrm{C}$ for $24 \mathrm{~h}$ ) and $\mathrm{CA}$ storage showed the best protective effect against bruising and fungal decay. This combined treatment decreased bull's eye rot by $86 \%$ and $60 \%$ and bitter rot by $73 \%$ and $65 \%$ in cv. Aroma and cv. Ingrid Marie, respectively, in comparison with untreated apples.
\end{abstract}

Most storage losses in the Swedish apple industry are caused by bruising and fungal decay. Harvesting and postharvest operations (especially grading, packing, and distribution) can cause a high degree of fruit bruising, resulting in a marked deterioration in quality (Ericsson, 1989). Although some bruising can be avoided by various orchard management practices (Tahir et al., 2005, 2007) and some storage systems can reduce fruit sensitivity to bruising, this problem is still difficult to

\footnotetext{
Received for publication 26 May 2009. Accepted for publication 31 July 2009.

We thank Dr. Salla Marttila, Swedish University of Agricultural Sciences, for assisting with microscopy (SEM). We also greatly acknowledge The Swedish Board of Agriculture for financial support of this study.

${ }^{1}$ To whom reprint requests should be addressed; e-mail ibrahim.tahir@1tj.slu.se.
}

eliminate (Funt et al., 1999; Grajkowski et al., 2004; Zhang, 1994). Clear knowledge on cultivar susceptibility to bruising and on the ability of postharvest nonchemical treatments to reduce this susceptibility is needed by growers and fruit distribution organizations.

Infections by Pezicula malicorticis (bull's eye rot), Penicillium expansum (blue mould), and Colletotrichum gloeosporioides (bitter rot) are the main causes of decay during apple storage in Sweden (Tahir, 2006). Because pre- and postharvest application of fungicides is becoming banned in increasingly more countries, and totally prohibited in organic production (such as in Sweden), more environmental-friendly methods to protect apples against the more common fungal diseases should be developed.

Postharvest heat treatment has been used to reduce fungal rots in apples (Ferguson et al., 2000; Saftner et al., 2003; Sholberg et al., 2000). Decay caused by $P$. expansum can be avoided by heating fruits at $38^{\circ} \mathrm{C}$ for 4 d (Conway et al., 1994; Fallik et al., 1995; Leverentz et al., 2000). Contradictory results have been found for C. gloeosporioides with some studies reporting a positive effect of heat treatment (Conway et al., 2004; Rappel et al., 1991) and others no effect (Janisiewicz et al., 2003). The effects of heat treatment on Pz. malicorticis have not been carefully studied. Regarding apple quality, some authors report that heat treatment leads to faster apple softening and a deterioration in apple acidity and starch content (Conway et al., 2004; Leverentz et al., 2003), whereas others found heated apples sweeter and firmer than nonheated (Abbott et al., 2000; Saftner et al., 2003). Heat treatment is not yet widely used because of variability in effects resulting from infection time (Leverentz et al., 2000), temperature degree and exposure period (Lurie, 1998), and weak residual protection (Leverentz et al., 2003). However, it is important to resolve these practical difficulties with heat treatment and to evaluate the usefulness of heating in combination with other treatments such as biocontrol (Conway et al., 2004).

The mode of action of heat treatment is still unclear. Previous works reported a direct interaction with fungal germination and growth (Schirra et al., 2000) and/or physiological responses by apple tissue (Ben-Shalom et al., 1996). Postharvest heating is reported to affect fruit ripening by enhancing peel degreening (Klein and Lurie, 1992) and starch conversion (Conway et al., 2004) and by delaying fruit softening and volatile production (Fallik et al., 1995). Apple epicuticular wax is relatively smooth with numerous surface cracks arranged in interconnected networks. These networks disappear after heating as a result of recrystallization or melting of the wax platelets into the cracks (Lurie et al., 1996; Roy et al., 1994; Schirra et al., 2000). However, the relationship between structural changes in epicuticular wax and the resistance of heat-treated fruits to rots is still unclear.

This study investigated relationships between bruise occurrence and fungal decay in two apple cultivars with postharvest heating alone or in combination with controlled atmosphere (CA) storage. The aim was to determine the shortest effective exposure period required to significantly decrease bruising, and fungal rots resulting from Pezicula malicorticis, and Colletotrichum gloeosporioides, and maintain fruit quality and thereby develop a commercially attractive method to decrease storage losses.

\section{Materials and Methods}

Apples. Two of the most commonly grown Swedish apple cultivars, cv. Aroma and cv. Ingrid Marie, were harvested from nonfungicide-treated trees at the experimental station orchard in Kivik, the Swedish University of Agricultural Sciences, during 2003-2006. Apples were picked at preclimacteric stage, when ethylene production 
was $4.0 \mathrm{pmol} \cdot \mathrm{kg}^{-1} \cdot \mathrm{s}^{-1}$, firmness was 79 to 82 $\mathrm{N}$, and starch conversion was $4 / 10$ for cv. Aroma and $3.0 \mathrm{pmol} \cdot \mathrm{kg}^{-1} \cdot \mathrm{s}^{-1}, 86$ to $88.0 \mathrm{~N}$, and $3 / 10$, respectively, for cv. Ingrid Marie (Tahir, 2006). After harvesting, apples were randomly divided into 65 lots per cultivar, 40 of which were used for pathogen experiments, 10 for quality control experiments, 10 for bruising experiments, and five for investigation of ethylene production and respiration rate. The first 60 lots comprised three replicate batches of 60 apples each, whereas the last five lots comprised three replicate batches of 150 apples each.

Pathogens. Of the 40 lots per cultivar, half were stored in air and the other half in CA storage after treatment. From each half:

1. Five lots were inoculated with conidial suspensions of $P z$. malicorticis. One was then left unheated (control), whereas the other four lots were heat-treated at $40 \pm$ $2{ }^{\circ} \mathrm{C}$ for $24,48,72$, or $96 \mathrm{~h}$.

2. Five lots were inoculated with conidial suspensions of $P$. expansum and then treated as in (1).

3. Five lots were inoculated with conidial suspensions of C. gloeosporioides, and then treated as in (1).

4. Five lots were used to investigate the natural infection (without inoculation). One was left unheated (control), whereas the other four lots were heat-treated at $40 \pm 2{ }^{\circ} \mathrm{C}$ for $24,48,72$, or $96 \mathrm{~h}$.

The three pathogens used were isolated from naturally infected apples showing typical symptoms of the diseases, maintained on petri dishes with potato dextrose agar, and stored separately as pure cultures at $4{ }^{\circ} \mathrm{C}$. Pathogen virulence over time was confirmed by periodic transfers through apples. For the present experiments, spores of the three pathogens were removed from the surface of 10-d-old cultures and suspended in $5 \mathrm{~mL}$ sterile distilled water containing $0.05 \%(\mathrm{v} / \mathrm{v})$ Tween 80. The suspensions were filtered through four layers of sterile cheesecloth to remove any adhering mycelia, and spore concentrations were adjusted to $1 \times 10^{5}$ conidia/mL (by hemacytometer). The apples used were washed for 2 min with water to remove natural occurring fungi and wounded twice on both sides to a depth of $2 \mathrm{~mm}$ with a nail (4 $\mathrm{mm}$ diameter); one wound was placed $10 \mathrm{~mm}$ above the equator and the other 10 $\mathrm{mm}$ below and inoculated by pipetting $20 \mu \mathrm{L}$ of freshly prepared conidial pathogen suspension into each of the wound sites.

Bruising. Of the 10 lots per cultivar used for the bruising experiments, half were stored in air and the other in CA storage. From each half, one lot was stored within $6 \mathrm{~h}$ of harvesting (control), and the other four lots were heat-treated at $40 \pm 2{ }^{\circ} \mathrm{C}$ for $24,48,72$, or $96 \mathrm{~h}$ before storage. After 4 months of storage, apples were tested for bruise susceptibility by dropping them from $30 \mathrm{~cm}$ through vertical hollow polyvinyl chloride pipe onto a wooden table. Bruised fruits were watched and examined after $12 \mathrm{~h}$ (when bruised area totally browned at room temperature). They were cut longitudinally; bruise depth (h), diameter (d), apple diameter (D) and altitude (x) were measured; and brown tissue was excised and weighed. Bruise susceptibility was estimated as: bruise volume $(\mathrm{BV})=6^{-1}$ $\Pi h d^{2}$ (Chen and Sun, 1981). To evaluate the relationship between coloration and bruise susceptibility, an additional lot of 150 apples per cultivar (cvs. Aroma and Ingrid Marie and their red phenotypes cv. Amorosa and cv. Karin Schneider) were picked at commercial harvesting dates, divided equally in three replicates each, and bruised within $6 \mathrm{~h}$ after picking by dropping them on their exposed or shaded side as described previously. Apple coloration of each side was measured as described subsequently.

Apple quality. Of the 10 lots per cultivar used for fruit quality experiments, half were stored in air and the other half in CA storage. One lot from each half was stored within $6 \mathrm{~h}$ of harvesting as control and the other four lots were heat-treated at $40 \pm 2{ }^{\circ} \mathrm{C}$ for $24,48,72$, or $96 \mathrm{~h}$. After storage, apple quality was monitored using 45 apples. Apple coloration was measured as hue angle $\left(h^{\circ}\right)$ using a Chromameter CR200 with a 8-mm diameter window (Minolta Ltd., Osaka, Japan). Measurements were conducted on three widely spaced spots at the apple equator and expressed as $\mathrm{h}^{\circ}$, in which $0^{\circ}=$ red-purple, $90^{\circ}=$ yellow, $180^{\circ}=$ bluish green, and $270^{\circ}=$ blue (McGuire, 1992). Apple firmness was determined by penetrometer (Model FT-327; Effigy, Alfonsine, Italy; plunger diameter $11.1 \mathrm{~mm}$, depth $7.9 \mathrm{~mm}$ ) on opposite sides of each apple and the results expressed as force (N) required for penetration. Soluble solids content (SSC) in apple juice was measured by a refractrometer (Atago, Tokyo, Japan) and the results expressed as a percentage. Titratable acidity was analyzed by titration of apple juice as malic acid with $0.05 \mathrm{~N} \mathrm{NaOH}$ to $\mathrm{pH}$ 8.1 (Radiometer PHM64, Copenhagen, Denmark). Storage rot (natural infection) was determined by visual examination according to Rein (1996). Decay severity resulting from artificial inoculation was measured as surface decay lesion area. Skin of heated and unheated apples was examined under a scanning electronic microscope (LEO 435VP, Cambridge, UK) with secondary electron detector at $2 \mathrm{kV}$ low voltage and on magnification $1000 \times$. Two apples per replicate batch and lot were assessed. Equatorial peel (4 to $5 \mathrm{~mm}^{2}$ ) from either the sun-exposed or shaded side of apples was freshly mounted on double-sided tape and on specimen stubs. Areas of wax at least $5 \mu \mathrm{m}$ thick were chosen.

Respiration activity and ethylene production. Of the five lots per cultivar used for respiration rate and ethylene production determination, one was left untreated (control), whereas the other four lots were heattreated on $40 \pm 2{ }^{\circ} \mathrm{C}$ for $24,48,72$, or $96 \mathrm{~h}$. All lots were stored in air $\left(21.0 \mathrm{kPa} \mathrm{O}_{2}+0.03 \mathrm{kPa}\right.$ $\mathrm{CO}_{2}, 2 \pm 0.5^{\circ} \mathrm{C}$ and $90 \%$ relative humidity). Once a week, six apples from each lot were transferred to 0.5 - $\mathrm{L}$ sealed glass jars (three replicate jars per treatment) for measurement of apple respiration rate and ethylene production. The jars were hermetically sealed with rubber stoppers for $2 \mathrm{~h}$ at $20^{\circ} \mathrm{C}$ before measurements. One milliliter of holder atmosphere was withdrawn by gas syringe and the ethylene quantified by gas chromatography, Agilent 6850 (column Agilent 19095P-Q04E Hp-Plot Q $30 \mathrm{~m} \times 530 \mu \mathrm{m} \times 40 \mu \mathrm{m})$. For respiration rate measurements $\left(\mathrm{CO}_{2}\right)$, one additional milliliter was analyzed by gas chromatography, Varian Inc. 3700 (twocolumn Hayesep Q1/4" $\times$ 8" and Molsict 5, $\left.3 / 8^{\prime \prime} \times 3^{\prime \prime}\right)$.

Heat treatment. At harvest, the field temperature of cv. Aroma and cv. Ingrid Marie was 16 and $14{ }^{\circ} \mathrm{C}$, respectively. Within $6 \mathrm{~h}$ of inoculation, apples were placed in separate new plastic boxes, covered with polyethylene to provide water-saturated conditions and to protect the apple from heat damage (Miller et al., 1990), and kept in thermostatically controlled $\left( \pm 2{ }^{\circ} \mathrm{C}\right)$ small chambers $\left(4.5 \mathrm{~m}^{3}\right)$ at $40{ }^{\circ} \mathrm{C}$ for $24,48,72$, or $96 \mathrm{~h}$. Relative humidity (RH) was always more than $80 \%$. The heated apples were allowed to equilibrate to room temperature for $12 \mathrm{~h}$ before being transferred to air or $\mathrm{CA}$ storage.

Storage and shelf life. Apples were stored either in air $\left(21.0 \mathrm{kPa} \mathrm{O}_{2}+0.03 \mathrm{kPa} \mathrm{CO}_{2}, 2 \pm\right.$ $0.5^{\circ} \mathrm{C}$ and $\left.90 \% \mathrm{RH}\right)$ or in $\mathrm{CA}\left(2.0 \mathrm{kPa} \mathrm{O}_{2}+\right.$ $2.0 \mathrm{kPa} \mathrm{CO}, 2{ }^{\circ} \mathrm{C}$ and $90 \% \mathrm{RH}$ ) (Haffner, 1993). CA storage conditions with computercontrolled gas composition were established in 350-L chambers (Nino-laboratory, Onsala, Sweden) $3 \mathrm{~d}$ before placing the apples in the chambers. At the end of storage, all apples were transferred to a plastic chamber $(18 \pm$ $2{ }^{\circ} \mathrm{C}$ and $80 \% \mathrm{RH}$ ) for 1 week before quality and natural and artificial infections with $P z$. malicorticis, $P$. expansum, and C. gloeosporioides were evaluated. Changes in quality parameters were also estimated.

Statistical analyses. The experiment was carried out over three seasons. Three variables were controlled: two storage methods, five exposure periods, and three seasons. Decay incidence was defined as the percentage of natural occurring fungal infection and decay severity was measured as surface decay lesion area caused by artificial infection. Data were subjected to arcsine square root transformation before analysis. Data were subjected to analyses of variance using the general linear model to determine main effects and interactions (SAS Inc., Cary, NC). Least significant difference values $(0.05)$ were calculated for comparison of means. Regression analyses and Pearson correlation were carried out (using SAS) to quantify the relationships among bruising occurrence, heat exposure time, and skin color.

\section{Results}

Apple quality. Fruit firmness at the end of shelf life was affected by cultivar, storage method, season, and treatment (Table $1 ; P<$ 0.05 ). The highest loss in firmness was found for control apples of either cultivar, whereas 
Table 1. Reduction of flesh firmness of heated and non heated apple fruits during storage and shelf life.

\begin{tabular}{|c|c|c|c|c|c|c|c|}
\hline \multirow[b]{2}{*}{ Control time } & \multirow{2}{*}{$\begin{array}{l}\text { Exposure } \\
\text { period }(\mathrm{h})\end{array}$} & \multicolumn{3}{|c|}{ Cultivar Aroma ${ }^{z}$} & \multicolumn{3}{|c|}{ Cultivar Ingrid Marie } \\
\hline & & 2003 & 2004 & 2005 & 2003 & 2004 & 2005 \\
\hline At harvest & & 80.0 & 82.0 & 79.0 & 88.0 & 86.0 & 87.0 \\
\hline \multirow{5}{*}{$\begin{array}{l}\text { After storage in air: } \\
21.0 \mathrm{kPa} \mathrm{O}_{2}+ \\
0.03 \mathrm{kPa} \mathrm{CO}_{2}\end{array}$} & (0) Control & $3.3 \mathrm{e}$ & $52.3 \mathrm{~d}$ & $50.0 \mathrm{e}$ & $5.0 \mathrm{f}$ & $59.7 \mathrm{f}$ & $57.3 \mathrm{c}$ \\
\hline & 24 & $54.0 \mathrm{~d}$ & $53.7 \mathrm{~cd}$ & $54.0 \mathrm{~d}$ & $61.7 \mathrm{e}$ & $61.7 \mathrm{f}$ & $64.3 \mathrm{~b}$ \\
\hline & 48 & $58.7 \mathrm{bcd}$ & $57.0 \mathrm{~b}$ & $59.0 \mathrm{bc}$ & $66.7 \mathrm{~cd}$ & $65.0 \mathrm{cde}$ & $65.0 \mathrm{~b}$ \\
\hline & 72 & $57.0 \mathrm{~cd}$ & $54.7 \mathrm{~cd}$ & $57.3 \mathrm{c}$ & $65.3 \mathrm{cde}$ & $62.0 \mathrm{ef}$ & $65.3 \mathrm{~b}$ \\
\hline & 96 & $56.0 \mathrm{~cd}$ & $56.0 \mathrm{bc}$ & $56.7 \mathrm{~cd}$ & $63.7 \mathrm{de}$ & $63.7 \mathrm{def}$ & $65.0 \mathrm{~b}$ \\
\hline After st & (0) & $56.0 \mathrm{~cd}$ & $56.2 \mathrm{bc}$ & $58.0 \mathrm{c}$ & $57.7 \mathrm{f}$ & $68.7 \mathrm{abc}$ & $64.7 \mathrm{~b}$ \\
\hline $2.0 \mathrm{kPa} \mathrm{O}_{2}+$ & 24 & $4.0 \mathrm{a}$ & $62.0 \mathrm{a}^{\mathrm{y}}$ & $64.3 \mathrm{a}^{\mathrm{y}}$ & $70.0 \mathrm{~b}$ & $70.3 \mathrm{ab}$ & $65.4 \mathrm{~b}$ \\
\hline \multirow[t]{3}{*}{$2.0 \mathrm{kPa} \mathrm{CO}_{2}$} & 48 & $66.7 \mathrm{a}^{\mathrm{y}}$ & $58.3 \mathrm{~b}$ & $61.0 \mathrm{~b}$ & $74.7 \mathrm{a}^{\mathrm{y}}$ & $72.3 \mathrm{a}^{\mathrm{y}}$ & $69.7 \mathrm{a}^{\mathrm{y}}$ \\
\hline & 72 & $59.7 \mathrm{bc}$ & $58.7 \mathrm{~b}$ & $59.3 \mathrm{~b}$ & $66.0 \mathrm{~cd}$ & $67.0 \mathrm{bcd}$ & $68.3 \mathrm{at}$ \\
\hline & 96 & $60.3 \mathrm{~b}$ & $61.3 \mathrm{a}$ & $59.7 \mathrm{~b}$ & $69.0 \mathrm{bc}$ & $66.3 \mathrm{~cd}$ & $65.3 \mathrm{~b}$ \\
\hline
\end{tabular}

${ }^{\mathrm{z}}$ Values are means of three replicates of 60 fruits each. $\mathrm{n}=1350$. Significant interaction was found between seasons and storage method-treatment at $P<0.05$.

${ }^{\mathrm{y}}$ Means followed by different letters within the same column are significantly different at least significant difference $=0.05$.

$\mathrm{CA}=$ controlled atmosphere.

the loss was significantly lower for apples heated at $40{ }^{\circ} \mathrm{C}$ for a minimum of $48 \mathrm{~h}$ ( or $24 \mathrm{~h}$ in 2003 for cv. Aroma and in 2005 for cv. Ingrid Marie) and for apples stored in CA (Table 1). Combined heat treatment (for $24 \mathrm{~h}$ for cv. Aroma and 48h for cv. Ingrid Marie) and CA storage maintained better firmness, showing $26 \%, 12 \%$, and $10 \%$ higher firmness in comparison with control, CA storage, and heat treatment (at $40{ }^{\circ} \mathrm{C}$ for 24 or $48 \mathrm{~h}$ ), respectively (Table 1 ). Extending the heat exposure period more than $24 \mathrm{~h}$ for cv. Aroma and $48 \mathrm{~h}$ for $\mathrm{cv}$. Ingrid Marie did not improve the effect of heat treatment on apple firmness, and instead had a negative influence for cv. Aroma in 2003 and 2005 (Table 1). No relationships were found between SSC or acidity and the heat treatments or CA storage in either cultivar, whereas heating apples at $40{ }^{\circ} \mathrm{C}$ for $24 \mathrm{~h}$ before CA storage improved the maintenance of the taste by $15 \%$ (higher acidity:SSC ratio) in comparison with other treatments (Table 2; $P<0.05$ ). Heat-treated apples had better coloration (lower $\mathrm{h}^{\circ}$ value) after shelf life compared with untreated fruit (Table 2). No interactions between treatment effect and season or between exposure period and col- oration were found. Nonheated apples (control) showed higher ethylene production than those heated at $40{ }^{\circ} \mathrm{C}$. This difference was first detectable in cv. Aroma after 5 weeks and in cv. Ingrid Marie after 6 weeks of air storage (Table $3 ; P<0.05$ ). Ethylene production was inversely related to exposure period. This effect became gradually visible until the last week in which the lowest ethylene production was found in apples heated at $40{ }^{\circ} \mathrm{C}$ for $96 \mathrm{~h}$ followed by heating for 72,48 , and $24 \mathrm{~h}$ (Table 3). Heat-treated apples showed higher respiration rate than nonheated during the first week in air storage, but this changed later (Weeks 5 to 7 in cv. Aroma and Weeks 3 to 7 in cv. Ingrid Marie) when nonheated apples showed a higher respiration rate than heat-treated apples. No visible influence of exposure time was observed in the beginning, whereas after 2 months of storage, heat-treated apples for 24 to $48 \mathrm{~h}$ showed higher respiration rate than heat-treated apples for $96 \mathrm{~h}$ (Table 4). The wax layer on the sun-exposed side of cv. Aroma apples usually had clumps (Fig. 1A1), whereas the wax layer on the shaded side often had nail-like crystals (Fig. 1A2). Cracks and fungal hyphae occurred on both

Table 2. Changes in skin color and fruit taste of heated and nonheated apple fruits during storage and shelf life.

\begin{tabular}{|c|c|c|c|c|c|}
\hline \multirow[b]{2}{*}{ Control time } & \multirow[b]{2}{*}{$\begin{array}{l}\text { Exposure } \\
\text { period (h) }\end{array}$} & \multicolumn{2}{|c|}{ Acidity/SSC $(\%)^{z}$} & \multicolumn{2}{|c|}{ Color $\left(\mathrm{h}^{\circ}\right)$ value $^{\mathrm{z}}$} \\
\hline & & $\begin{array}{c}\text { Cultivar } \\
\text { Aroma }\end{array}$ & $\begin{array}{c}\text { Cultivar Ingrid } \\
\text { Marie }\end{array}$ & $\begin{array}{l}\text { Cultivar } \\
\text { Aroma }\end{array}$ & $\begin{array}{c}\text { Cultivar } \\
\text { Ingrid Marie }\end{array}$ \\
\hline At harvest & & 9.0 & 8.3 & 91.3 & 35.6 \\
\hline After storage in air: & (0) Control & $4.1 \mathrm{e}$ & $4.2 \mathrm{~b}$ & $80.1 \mathrm{a}^{\mathrm{y}}$ & $33.2 \mathrm{a}^{\mathrm{y}}$ \\
\hline $21.0 \mathrm{kPa} \mathrm{O}_{2}+$ & 24 & 4.4 cde & $4.4 \mathrm{ab}$ & $67.4 \mathrm{~b}$ & $28.3 \mathrm{~b}$ \\
\hline \multirow{3}{*}{$0.03 \mathrm{kPa} \mathrm{CO}_{2}$} & 48 & $4.5 \mathrm{bcd}$ & $4.6 \mathrm{ab}$ & $67.0 \mathrm{~b}$ & $28.9 \mathrm{~b}$ \\
\hline & 72 & 4.4 cde & $4.7 \mathrm{ab}$ & $66.8 \mathrm{~b}$ & $29.1 \mathrm{~b}$ \\
\hline & 96 & $4.5 \mathrm{bcd}$ & $4.5 \mathrm{ab}$ & $66.8 \mathrm{~b}$ & $28.2 \mathrm{~b}$ \\
\hline After storage in CA: & (0) & $4.2 \mathrm{de}$ & $4.2 \mathrm{~b}$ & $86.8 \mathrm{a}$ & $35.1 \mathrm{a}$ \\
\hline $2.0 \mathrm{kPa} \mathrm{O}+$ & 24 & $4.9 \mathrm{a}^{\mathrm{y}}$ & $4.8 \mathrm{a}$ & $72.1 \mathrm{~b}$ & $30.4 \mathrm{~b}$ \\
\hline \multirow[t]{3}{*}{$2.0 \mathrm{kPa} \mathrm{CO} 2$} & 48 & $4.8 \mathrm{ab}$ & $4.9 \mathrm{a}^{\mathrm{y}}$ & $71.0 \mathrm{~b}$ & $28.9 \mathrm{~b}$ \\
\hline & 72 & $4.7 \mathrm{abc}$ & $4.9 \mathrm{a}$ & $71.0 \mathrm{~b}$ & $30.7 \mathrm{~b}$ \\
\hline & 96 & $4.6 \mathrm{abc}$ & $4.6 \mathrm{ab}$ & $71.6 \mathrm{~b}$ & $29.6 \mathrm{~b}$ \\
\hline
\end{tabular}

${ }^{2}$ Values are transformed means of three seasons, three replicates of 60 fruits each. $n=450$, because no significant interaction was noted between seasons treatments at $P<0.05$. Significant interaction was found only between storage methods and exposure periods.

${ }^{y}$ Means followed by different letters within the same column are significantly different at least significant difference $=0.05$.

$\mathrm{SSC}=$ soluble solids content; $\mathrm{CA}=$ controlled atmosphere. sides, but particularly on the shaded side (Fig. 1A3). Wax layers in cv. Ingrid Marie were heavier, thicker, and less homogenous than those in cv. Aroma. Wax with nail-like crystals, microcracks, and fungal hyphae were found on both sun-exposed (Fig. 2A1) and shaded sides (Fig. 2A2).

Bruising. Bruising after storage was affected by cultivar, season, and fruit side. Cultivar Aroma and cv. Ingrid Marie apples were significantly $(P<0.05)$ more sensitive to bruising than the respective red phenotype $\mathrm{cv}$. Amorosa (by $15 \%$ on the shaded side and $12 \%$ on the sun-exposed side) and cv. Karin Schneider (by $14 \%$ on the shaded side and $10 \%$ on the sun-exposed side during only two seasons) (Table 5). The shaded side of fruit was more sensitive (larger BV) to bruising than the sun-exposed side (Table 5). Generally, a positive Pearson correlation was found between $h^{\circ}$ value and bruise occurrence with fruit with high $h^{\circ}$ value (poor red color) showing larger BV than fruit with low $\mathrm{h}^{\circ}$ value (Table 5). Heating apples decreased bruise susceptibility (lower BV) in both cultivars (Table 6). A positive correlation was found between heat exposure period and BV. The shortest effective exposure period (at $40{ }^{\circ} \mathrm{C}$ ) was $24 \mathrm{~h}$ in $\mathrm{cv}$. Aroma, decreasing $\mathrm{BV}$ by $58 \%$, and $48 \mathrm{~h}$ in cv. Ingrid Marie, decreasing $\mathrm{BV}$ by $43 \%$, compared with unheated fruits (Table 6). A combination of postharvest heat treatment (at $40{ }^{\circ} \mathrm{C}$ for $24 \mathrm{~h}$ ) and CA storage increased the positive effect of each separate treatment on bruise susceptibility of the two cultivars. This combined treatment reduced $\mathrm{BV}$ by $54 \%$ and $40 \%$ compared with only CA storage and by $23 \%$ and $35 \%$ compared with only heat treatment (at $40{ }^{\circ} \mathrm{C}$ for $24 \mathrm{~h}$ as shortest effective period) in cv. Aroma and cv. Ingrid Marie apples, respectively (Table 6). No significant interactions with season were noted.

Fungal decay resulting from natural infection. Natural decay incidence was affected by cultivar, decay-causing agent, season, storage method, and treatment. Cultivar Ingrid Marie apples showed more resistance to Pz. malicorticis than cv. Aroma apples (by 30\%), whereas cv. Aroma was always more sensitive to $P$. expansum than cv. Ingrid Marie (by 40\%). Resistance to $C$. gloeosporioides varied between the seasons (data not shown). CA storage decreased decay resulting from the three pathogens by $50 \%$ compared with the air stored cv. Aroma apples (Table 7) and by 50\%, 38\%, and $27 \%$ resulting from Pz. malicorticis, C. gloeosporioides, and $P$. expansum, respectively, compared with the air stored cv. Ingrid Marie apples (Table 7). Heat treatment at $40{ }^{\circ} \mathrm{C}$ for $24 \mathrm{~h}$ reduced storage decay in cv. Aroma as a result of each of the three pathogens by $28 \%$ in air and $62 \%$ in CA (Table 7), whereas decay resulting from $P z$. malicorticis and $C$. gloeosporioides in cv. Ingrid Marie apples was also decreased by $25 \%$ and $33 \%$ in fruits stored in air and by $50 \%$ and $38 \%$ in fruits stored in CA, respectively, in comparison with control. This positive influence on decay 
Table 3. Ethylene production in heated and non heated apple fruits during storage in air.

\begin{tabular}{lccccr}
\hline & \multirow{2}{*}{$\begin{array}{c}\text { Heating } \\
\text { Cultivar }\end{array}$} & \multicolumn{3}{c}{ Ethylene production $\left(\mathrm{pmol} \cdot \mathrm{kg}^{-1} \cdot \mathrm{s}^{-1}\right)$} & during storage in air $(\text { weeks })^{\mathrm{z}}$ \\
\cline { 2 - 6 } & at $40{ }^{\circ} \mathrm{C}$ for: & Week 5 & Week 6 & Week 7 & Week 8 \\
\hline Aroma & $0 \mathrm{~h} \mathrm{Control}$ & $147.2 \mathrm{a}^{\mathrm{y}}$ & $490.5 \mathrm{a}$ & $790.0 \mathrm{a}$ & $1,222.8 \mathrm{a}$ \\
& $24 \mathrm{~h}$ & $62.8 \mathrm{~b}$ & $182.8 \mathrm{~b}$ & $298.5 \mathrm{~b}$ & $863.8 \mathrm{~b}$ \\
& $48 \mathrm{~h}$ & $101.9 \mathrm{ab}$ & $139.2 \mathrm{bc}$ & $223.0 \mathrm{bc}$ & $725.2 \mathrm{c}$ \\
& $72 \mathrm{~h}$ & $100.7 \mathrm{ab}$ & $98.4 \mathrm{c}$ & $178.3 \mathrm{~cd}$ & $630.7 \mathrm{~d}$ \\
Ingrid Marie & $96 \mathrm{~h}$ & $97.9 \mathrm{ab}$ & $81.3 \mathrm{c}$ & $135.5 \mathrm{~d}$ & $505.2 \mathrm{e}$ \\
& $0 \mathrm{~h} \mathrm{Control}$ & $111.0 \mathrm{~A}$ & $444.2 \mathrm{~A}$ & $1,018.5 \mathrm{~A}$ & $1,376.9 \mathrm{~A}$ \\
& $24 \mathrm{~h}$ & $89.4 \mathrm{~A}$ & $228.8 \mathrm{~B}$ & $334.2 \mathrm{~B}$ & $722.6 \mathrm{~B}$ \\
& $48 \mathrm{~h}$ & $85.5 \mathrm{~A}$ & $187.7 \mathrm{BC}$ & $230.4 \mathrm{C}$ & $626.9 \mathrm{C}$ \\
& $72 \mathrm{~h}$ & $84.4 \mathrm{~A}$ & $156.2 \mathrm{BC}$ & $176.6 \mathrm{CD}$ & $505.4 \mathrm{D}$ \\
& $96 \mathrm{~h}$ & $82.2 \mathrm{~A}$ & $107.5 \mathrm{C}$ & $134.3 \mathrm{D}$ & $403.3 \mathrm{E}$ \\
\hline
\end{tabular}

${ }^{2}$ Values are means of two seasons, three replicate of one fruit each. $\mathrm{n}=240$, because no significant interaction was noted between seasons-treatments at $P<0.05$. Significant interaction was only found between exposure period and storage week at $P<0.05$, starting in Week 6 .

${ }^{y}$ Means followed by different letters within the same column are significantly different at least significant difference $=0.05$; lower case letter refers to 'Aroma' and upper case letter refers to 'Ingrid Marie'.

Table 4. Respiration rate $\left(\mathrm{CO}_{2}\right.$ production) in heated and nonheated apple fruits during storage in air.

\begin{tabular}{lccccccccc}
\hline & Heating & \multicolumn{6}{c}{$\mathrm{CO}_{2}$ production $\left(\mathrm{pmol}^{\circ} \mathrm{kg}^{-1} \cdot \mathrm{s}^{-1}\right)$ during storage in air (weeks $)^{\mathrm{z}}$} \\
\cline { 3 - 10 } Cultivar & at $40{ }^{\circ} \mathrm{C}$ for & 1 & 2 & 3 & 4 & 5 & 6 & 7 & 8 \\
\hline Aroma & $0 \mathrm{~h} \mathrm{Control}$ & $42.7 \mathrm{~b}^{\mathrm{y}}$ & $54.7 \mathrm{a}$ & $72.2 \mathrm{a}$ & $86.7 \mathrm{a}$ & $115.4 \mathrm{a}$ & $129.7 \mathrm{a}$ & $137.8 \mathrm{a}$ & $161.9 \mathrm{a}$ \\
& $24 \mathrm{~h}$ & $62.3 \mathrm{a}$ & $51.8 \mathrm{a}$ & $62.3 \mathrm{a}$ & $72.3 \mathrm{a}$ & $65.9 \mathrm{~b}$ & $76.8 \mathrm{~b}$ & $87.3 \mathrm{~b}$ & $117.4 \mathrm{~b}$ \\
& $48 \mathrm{~h}$ & $60.4 \mathrm{a}$ & $54.4 \mathrm{a}$ & $67.7 \mathrm{a}$ & $73.6 \mathrm{a}$ & $70.7 \mathrm{~b}$ & $81.3 \mathrm{~b}$ & $84.3 \mathrm{~b}$ & $107.5 \mathrm{~b}$ \\
& $72 \mathrm{~h}$ & $61.0 \mathrm{a}$ & $52.3 \mathrm{a}$ & $68.8 \mathrm{a}$ & $68.0 \mathrm{a}$ & $63.2 \mathrm{~b}$ & $74.7 \mathrm{~b}$ & $80.1 \mathrm{~b}$ & $99.2 \mathrm{bc}$ \\
& $96 \mathrm{~h}$ & $63.4 \mathrm{a}$ & $49.2 \mathrm{a}$ & $65.3 \mathrm{a}$ & $67.6 \mathrm{a}$ & $67.1 \mathrm{~b}$ & $70.3 \mathrm{~b}$ & $78.6 \mathrm{~b}$ & $77.9 \mathrm{c}$ \\
Ingrid Marie & $0 \mathrm{~h} \mathrm{Control}$ & $48.0 \mathrm{~B}$ & $61.5 \mathrm{~A}$ & $81.2 \mathrm{~A}$ & $97.4 \mathrm{~A}$ & $110.5 \mathrm{~A}$ & $114.8 \mathrm{~A}$ & $143.7 \mathrm{~A}$ & $170.7 \mathrm{~A}$ \\
& $24 \mathrm{~h}$ & $64.3 \mathrm{~A}$ & $58.2 \mathrm{~A}$ & $63.3 \mathrm{~B}$ & $81.3 \mathrm{~B}$ & $74.0 \mathrm{~B}$ & $73.2 \mathrm{~B}$ & $98.1 \mathrm{~B}$ & $126.3 \mathrm{~B}$ \\
& $48 \mathrm{~h}$ & $65.2 \mathrm{~A}$ & $61.1 \mathrm{~A}$ & $64.7 \mathrm{~B}$ & $82.7 \mathrm{AB}$ & $79.5 \mathrm{~B}$ & $74.5 \mathrm{~B}$ & $94.7 \mathrm{~B}$ & $120.8 \mathrm{~B}$ \\
& $72 \mathrm{~h}$ & $65.8 \mathrm{~A}$ & $58.8 \mathrm{~A}$ & $66.8 \mathrm{~B}$ & $76.4 \mathrm{~B}$ & $78.5 \mathrm{~B}$ & $76.3 \mathrm{~B}$ & $90.0 \mathrm{~B}$ & $111.5 \mathrm{BC}$ \\
& $96 \mathrm{~h}$ & $65.8 \mathrm{~A}$ & $55.3 \mathrm{~A}$ & $64.0 \mathrm{~B}$ & $82.5 \mathrm{AB}$ & $86.2 \mathrm{~B}$ & $79.0 \mathrm{~B}$ & $88.3 \mathrm{~B}$ & $102.5 \mathrm{C}$ \\
\hline
\end{tabular}

${ }^{2}$ Values are means of two seasons, three replicate of one fruit each. $\mathrm{n}=240$, because no significant interaction was noted between seasons treatments at $P<0.05$. Significant interaction was only found between exposure period and storage week at $P<0.05$.

${ }^{y}$ Means followed by different letters within the same column are significantly different at least significant difference $=0.05$; lower case letter refers to $\mathrm{cv}$. Aroma and upper case letter refers to cv. Ingrid Marie.
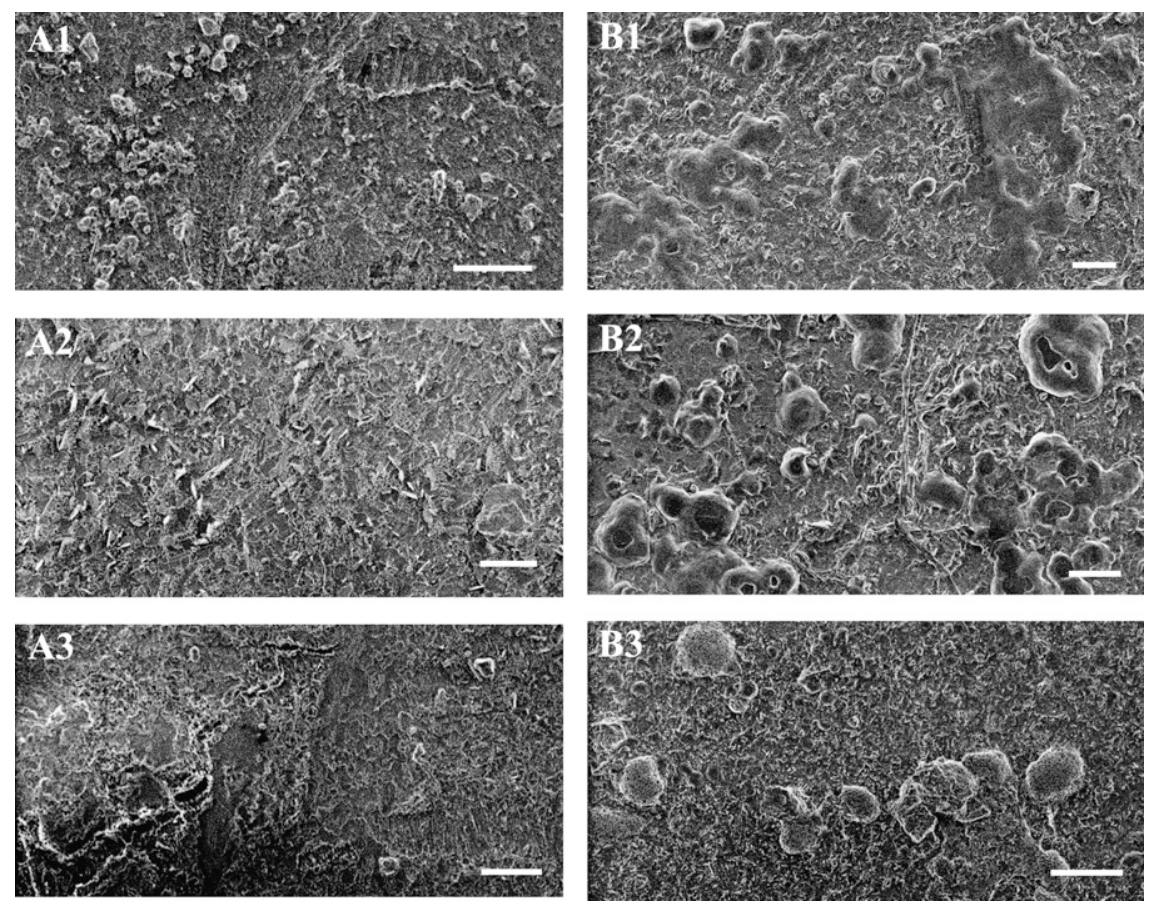

Fig. 1. Epicuticular wax in cv. Aroma apples (A) in untreated and (B) in heat-treated apples at $40^{\circ} \mathrm{C}$ for $24 \mathrm{~h}$. Scale bars $=5 \mu \mathrm{m}$, magnification $1000 \times$; Leo. 435 up. (A1) Wax clumps on sun-exposed side. (A2) Nail-like wax crystals on shaded side. (A3) Crack in wax layer, shaded side. (B1) Wax clumps fusing as a result of heat treatment. (B2) Fungal hyphae captured in melted wax. (B3) Wax layer on shaded side less influenced by heat treatment. caused by $P$. expansum was shown only when heat treatment was combined with CA storage (Table 7).

Fungal decay resulting from artificial inoculation. Decay resulting from artificial inoculation was affected by cultivar, decaycausing agent, storage method, and treatment. In both cultivars, Pz. malicorticis caused the largest lesion area (13.0 to 17.0 $\mathrm{cm}^{2}$ ) followed by $P$. expansum (8.2 to 14.0 $\mathrm{cm}^{2}$ ), whereas C. gloeosporioides gave the smallest lesions (4.0 to $4.8 \mathrm{~cm}^{2}$ ). Heating apples at $40{ }^{\circ} \mathrm{C}$ for $24 \mathrm{~h}$ in air gave $50 \%, 63 \%$, and $56 \%$ smaller lesion area in cv. Aroma and $48 \%, 56 \%$, and $32 \%$ smaller lesion area in cv. Ingrid Marie resulting from inoculation with $P$ z. malicorticis, C. gloeosporioides, and $P$. expansum, respectively, compared with the nonheat-treated apples (Table 8). The shortest protective exposure period was $24 \mathrm{~h}$, because no further beneficial effect with longer exposure periods was observed (Table 8). CA storage decreased decay severity resulting from $P z$. malicorticis, C. gloeosporioides, and $P$. expansum by $53 \%, 52 \%$, and $50 \%$ in $\mathrm{cv}$. Aroma and by $40 \%, 16 \%$, and $50 \%$ in cv. Ingrid Marie, respectively, in comparison with the air-stored apples (Table 8). Combined heat treatment $\left(40^{\circ} \mathrm{C}\right.$ for $\left.24 \mathrm{~h}\right)$ and CA storage improved resistance to $P z$. malicorticis, C. gloeosporioides, and $P$. expansum further and resulted in lower decay severity compared with only CA-stored apples (by $60 \%, 70 \%$, and $50 \%$, respectively, in cv. Aroma apples and by $60 \%, 57 \%$, and $40 \%$ in cv. Ingrid Marie) (Table 8 ).

Changes in skin wax. Heat treatment caused important changes in epicuticular wax. After heating of cv. Aroma apples at $40{ }^{\circ} \mathrm{C}$ for $24 \mathrm{~h}$, wax clumps started to fuse together to discernibly continuous parallel layers (Figs. 1B1 and 2B1) with occasional remains of fungal hyphae captured in the wax (Figs. 1B3 and 2B3). However, the degree of wax fusion varied even within the same apple. The nail-like wax crystals held their form longer than the wax clumps (Fig. 2B2). Heating had less effect on the wax structure of cv. Ingrid Marie apples. However, microcrack structure was altered by heating and filled with melted wax (Figs. 1B1 and 2B1) Fungal hyphae were also captured in the wax (Figs. 1B3 and 2B3).

\section{Discussion}

Bruising was not totally prevented by CA storage, but bruise volume was decreased by combining CA storage with heat treatment at $40{ }^{\circ} \mathrm{C}$ for $24 \mathrm{~h}$, to commercially acceptable levels in both cultivars, because apples with bruised area smaller than $1 \mathrm{~cm}^{3}$ in volume were accepted by consumers (Ericsson and Tahir, 1996). The inhibitory effect of heat treatment on ethylene production and uronic acid degradation (Klein et al., 1990) and synthesis of cell wall hydrolytic enzymes such as polygalacturonase (Lurie et al., 1996), resulting in better firmness might cause higher ability to withstand impact injury. A clear correlation was found between 
apple red color and resistance to bruising, because shaded sides were more sensitive to impacts than sun-exposed sides. Also, cvs. Aroma and Ingrid Marie had higher bruise susceptibility than their red phenotypes cvs.

Amorosa and Karin Schneider. The sunexposed side of apples contained thicker and more numerous wax clumps than the shaded side. Heat treatment is known to melt skin wax and change its structure (Roy et al.,

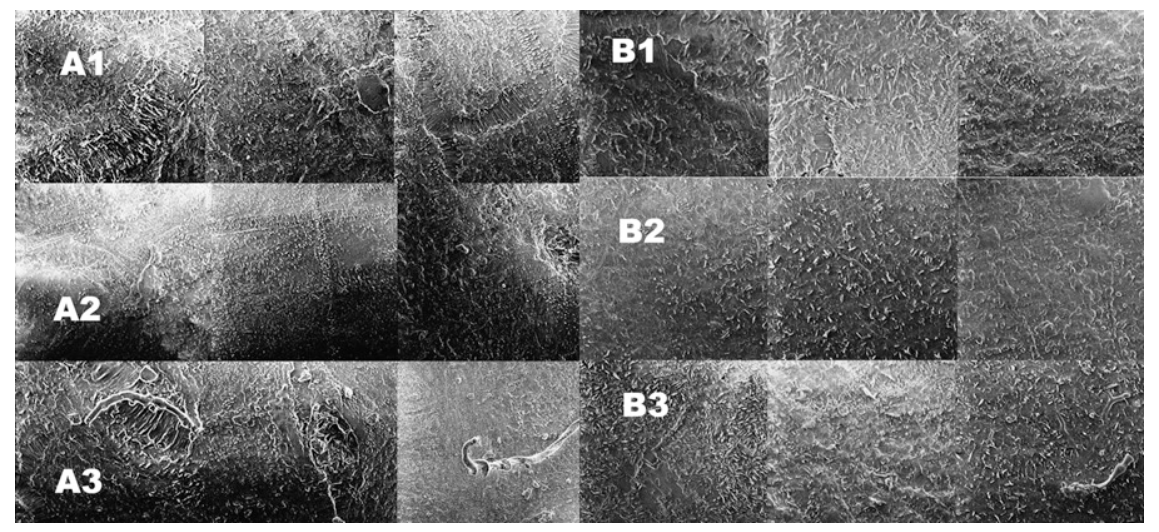

Fig. 2. Epicuticular wax in cv. Ingrid Marie apples (A) in untreated and (B) in heat-treated apples at $40^{\circ} \mathrm{C}$ for $24 \mathrm{~h}$. Scale bars $=5 \mu \mathrm{m}$, magnification 1000x; Leo. 435 up. (A1) Layers of nail-like wax crystals on shaded side. (A2) Wax clumps and nail-like crystals on exposed side. (A3) Crack and hyphae in the wax layer. (B1) Wax clumps fusing very slowly resulting from heat treatment. (B2) Melted wax filling cracks. (B3) Fungal hyphae captured in melted wax.
1994), perhaps providing some cushioning and decreasing the impact pressure. Cultivar Ingrid Marie apples, which had thicker, naillike, and heavier wax, also had higher resistance to bruising than $\mathrm{cv}$. Aroma.

C. gloeosporioides did not cause severe decay in either cultivar, whereas the dominant storage pathogen was Pz. maliorticis followed by $P$. expansum. Both of these fungal species were the more aggressive pathogens and not only $P$. expansum as previously suggested (Conway et al., 2004; Janisiewicz et al., 2003). All three pathogens were sensitive to heat treatment (at $40{ }^{\circ} \mathrm{C}$ ) reducing natural fungal infection or decay resulting from artificial inoculation of apples. The effectiveness of heat treatment depended on cultivar and decay-causing agent, confirming previous studies (Barkai-Golan and Philips, 1991; Spadaro et al., 2004), although the present study did not indicate any positive effect of extending heat exposure period on the reduction of the decay.

Shortening the exposure period of heat treatment from 96 to $24 \mathrm{~h}$ did not cause any negative change in the method effectiveness. Heating apples for longer than $48 \mathrm{~h}$ increased

Table 5. Relationships between apple color and bruise occurrence.

\begin{tabular}{|c|c|c|c|c|c|c|c|c|c|c|c|}
\hline \multirow[b]{2}{*}{ Cultivar } & \multirow[b]{2}{*}{ Group } & \multirow[b]{2}{*}{$\begin{array}{l}\text { Bruised } \\
\text { side }\end{array}$} & \multicolumn{3}{|c|}{2003} & \multicolumn{3}{|c|}{2004} & \multicolumn{3}{|c|}{2005} \\
\hline & & & BV $(\%)^{z}$ & $\begin{array}{c}\text { Red } \\
\text { color }\left(h^{\circ}\right)^{y}\end{array}$ & $\begin{array}{c}\text { Pearson } \\
\text { correlation }\end{array}$ & BV $(\%)^{z}$ & $\begin{array}{c}\text { Red } \\
\text { color }\left(h^{\circ}\right)^{y}\end{array}$ & $\begin{array}{c}\text { Pearson } \\
\text { correlation }\end{array}$ & BV $(\%)^{z}$ & $\begin{array}{l}\text { Red color } \\
\left(\mathrm{h}^{\circ}\right)^{\mathrm{y}}\end{array}$ & $\begin{array}{c}\text { Pearson } \\
\text { correlation }\end{array}$ \\
\hline \multirow[t]{4}{*}{ Aroma } & Standard & Shaded & $3.2 \mathrm{a}^{\mathrm{x}}$ & $120.9 \mathrm{a}$ & $0.99 * * *$ & $3.0 \mathrm{a}$ & $114.5 \mathrm{a}$ & $0.84 * * *$ & $2.9 \mathrm{a}$ & $128.0 \mathrm{a}$ & $0.92 * * *$ \\
\hline & & Exposed & $2.6 \mathrm{~b}$ & $82.3 \mathrm{~b}$ & $0.40 *$ & $2.8 \mathrm{~b}$ & $76.3 \mathrm{~b}$ & $0.88 * * *$ & $2.7 \mathrm{~b}$ & $83.3 \mathrm{~b}$ & $0.97 * * *$ \\
\hline & Red & Shaded & $2.7 \mathrm{~b}$ & $59.9 \mathrm{c}$ & $0.85^{* * *}$ & $2.6 \mathrm{c}$ & $54.7 \mathrm{c}$ & $0.99 * * *$ & $2.5 \mathrm{c}$ & $49.1 \mathrm{c}$ & $0.98 * * *$ \\
\hline & & Exposed & $2.4 \mathrm{c}$ & $52.1 \mathrm{~d}$ & $0.21 *$ & $2.4 \mathrm{~d}$ & $39.1 \mathrm{~d}$ & $0.74 * *$ & $2.5 \mathrm{c}$ & $46.7 \mathrm{c}$ & $0.62 * *$ \\
\hline \multirow[t]{4}{*}{ Ingrid Marie } & Standard & Shaded & $2.5 \mathrm{a}^{\mathrm{x}}$ & $55.0 \mathrm{a}$ & $0.99 * * *$ & $2.5 \mathrm{a}$ & $54.8 \mathrm{a}$ & $0.99 * * *$ & $2.4 \mathrm{a}$ & $37.0 \mathrm{a}$ & $0.54^{*}$ \\
\hline & & Exposed & $2.3 \mathrm{~b}$ & $28.3 \mathrm{~b}$ & $0.99 * * *$ & $2.1 \mathrm{bc}$ & $30.7 \mathrm{~b}$ & $0.94 * * *$ & $2.2 \mathrm{~b}$ & $24.4 \mathrm{~b}$ & $0.81 * * *$ \\
\hline & Red & Shaded & $2.3 \mathrm{~b}$ & $27.3 \mathrm{~b}$ & $0.89 * * *$ & $2.2 \mathrm{~b}$ & $21.5 \mathrm{c}$ & 0.45 & $2.0 \mathrm{c}$ & $20.7 \mathrm{c}$ & 0.24 \\
\hline & "K. S." & Exposed & $2.1 \mathrm{c}$ & $20.3 \mathrm{c}$ & $0.62 * *$ & $2.0 \mathrm{c}$ & $19.3 \mathrm{c}$ & $0.57 *$ & $1.9 \mathrm{c}$ & $20.0 \mathrm{c}$ & $0.96 * * *$ \\
\hline
\end{tabular}

Fruits were bruised within $6 \mathrm{~h}$ after harvesting.

${ }^{\mathrm{z}} \mathrm{BV}=$ bruise volume percentage (bruise volume $*$ fruit volume $\mathrm{e}^{-1}$ ).

${ }^{\mathrm{y}}$ Lower $\mathrm{h}^{\circ}$ means better red coloration. Values are transformed means of three replicates of 50 fruits each. $\mathrm{n}=150$.

${ }^{\mathrm{x}}$ Means followed by different letters within the same column and cultivar are significantly different at least significant difference $=0.05$.

$*, * * * * *=$ Significant at $P<0.05,0.01$, and 0.001 , respectively. Interactions cultivar-fruit side, cultivar-season, fruit side-season were significant at $P<0.05$.

"K.S." = cv. Karin Schneider; Red Aroma = cv. Amorosa.

Table 6. Postharvest heating at $40{ }^{\circ} \mathrm{C}$ increases apple resistance to bruising (average of the means 2003-2005).

\begin{tabular}{|c|c|c|c|c|c|}
\hline Storage methods & $\begin{array}{l}\text { Treatment } \\
\text { period }(\mathrm{h})\end{array}$ & $\begin{array}{l}\text { Cultivar } \\
\text { Aroma BV } \\
(\%)^{z}\end{array}$ & $\begin{array}{c}\text { Pearson } \\
\text { correlation }(\mathrm{r}) \\
\text { between bruising } \\
\text { and heat-exposure } \\
\text { periods }\end{array}$ & $\begin{array}{l}\text { Cultivar } \\
\text { Ingrid } \\
\text { Marie BV } \\
(\%)^{z}\end{array}$ & $\begin{array}{c}\text { Pearson } \\
\text { correlation (r) } \\
\text { between bruising } \\
\text { and heat-exposure } \\
\text { periods }\end{array}$ \\
\hline $\begin{array}{l}\text { Air: } 21.0 \mathrm{KPa} \mathrm{O}_{2} \\
\quad \text { and } 0.03 \mathrm{KPa} \mathrm{CO}_{2}\end{array}$ & $\begin{array}{c}0 \text { h Control } \\
24 \\
48 \\
72 \\
96\end{array}$ & $\begin{array}{l}3.1 \mathrm{a}^{\mathrm{y}} \\
1.3 \mathrm{~g} \\
1.6 \mathrm{ef} \\
1.9 \mathrm{~cd} \\
2.0 \mathrm{bc}\end{array}$ & $0.85 * *$ & $\begin{array}{l}2.3 \mathrm{a}^{\mathrm{y}} \\
1.7 \mathrm{bc} \\
1.3 \mathrm{de} \\
1.5 \mathrm{~cd} \\
2.1 \mathrm{ab}\end{array}$ & $0.57^{*}$ \\
\hline $\begin{array}{c}\text { CA storage: } 2.0 \mathrm{KPa} \mathrm{O}_{2} \\
\text { and } 2.0 \mathrm{KPa} \mathrm{CO}\end{array}$ & $\begin{array}{r}0 \mathrm{~h} \\
24 \\
48 \\
72 \\
96\end{array}$ & $\begin{array}{l}2.2 \mathrm{~b} \\
0.9 \mathrm{~h} \\
1.4 \mathrm{fg} \\
1.5 \mathrm{efg} \\
1.7 \mathrm{de}\end{array}$ & $0.84 * *$ & $\begin{array}{l}1.9 \mathrm{~b} \\
1.2 \mathrm{ef} \\
0.8 \mathrm{~g} \\
1.1 \mathrm{ef} \\
1.5 \mathrm{~cd}\end{array}$ & 0.37 \\
\hline
\end{tabular}

${ }^{\mathrm{z}}$ Fruits were bruised after storage and all values are means of the bruise volume on both fruit sides. BV values: bruise volume percentage (bruise volume $*$ fruit volume $^{-1}$ ) are transformed means of three seasons (2003-2005) and three replicates of 540 bruised areas.

${ }^{\mathrm{y}}$ Means followed by different letters within a column for bruise volume are significantly different at least significant difference $=0.05$. Mean squares from GLM analyses of bruise volume: between exposure periods significant at $P<0.05$, interaction exposure periods-storage method was significant at $P<0.05$, and between period-season was not significant at $P<0.05$.

$*, * *, * * *=$ Significant at $P<0.5,0.01$, and 0.001 , respectively.

$\mathrm{CA}=$ controlled atmosphere. 
Table 7. Natural fungal decay in heated and nonheated apples after 4 months of storage and 1-week shelf life.

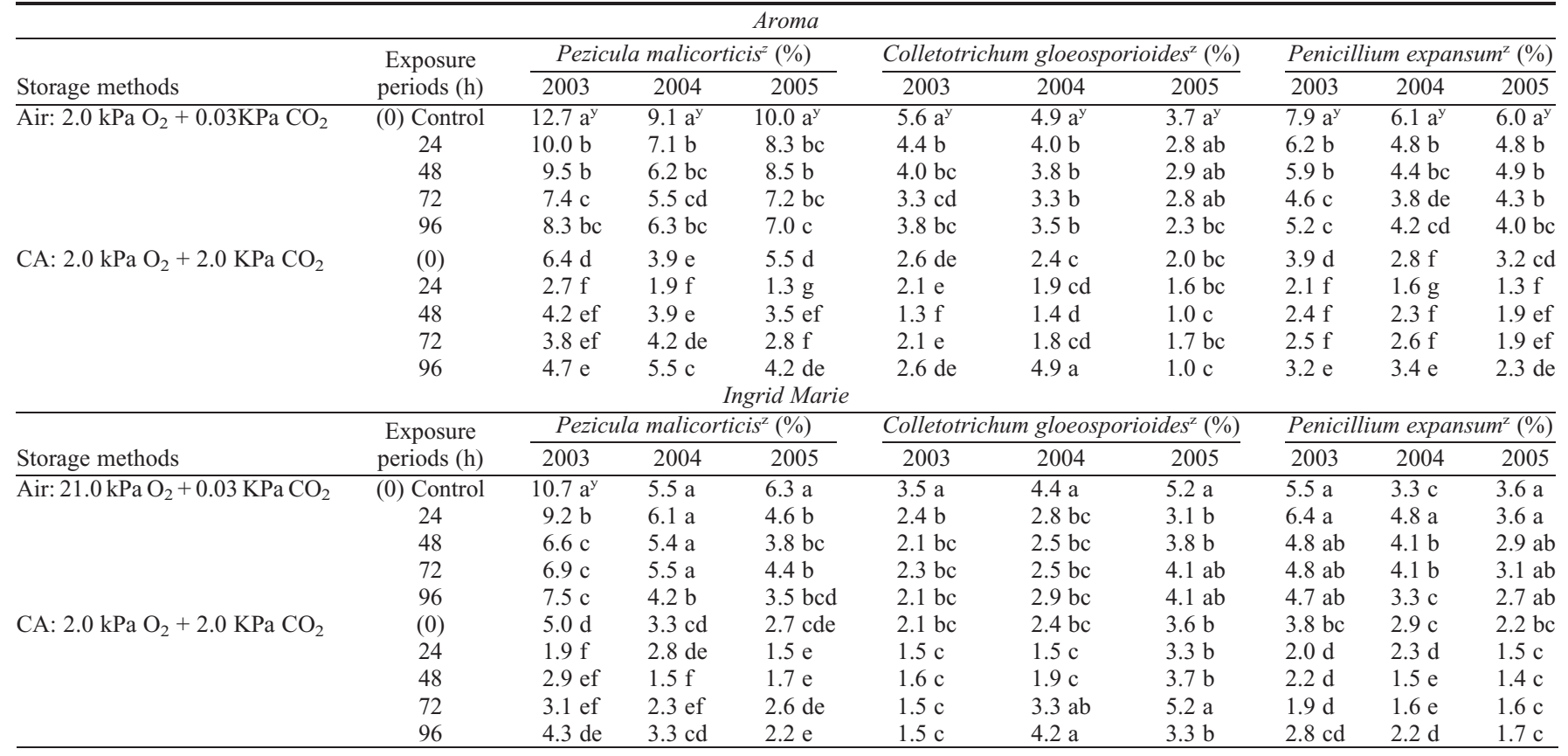

${ }^{2}$ Values are transformed means of three replicates of 60 fruits each. $n=1800$. Interactions cultivar-agent, cultivar-season, agent-season, cultivar-storage method, and storage method-agent were significant at $P<0.05$.

${ }^{y}$ Means followed by different letters within the same column are significantly different at least significant difference $=0.05$.

$\mathrm{CA}=$ controlled atmosphere.

Table 8. Improvement of apple resistance to fungal decay [as lesion area $\left(\mathrm{cm}^{2}\right)$ ] by postharvest heating and controlled atmosphere (CA) storage (means 20032005).

\begin{tabular}{|c|c|c|c|c|c|c|c|}
\hline \multirow[b]{2}{*}{ Storage methods } & \multirow[b]{2}{*}{$\begin{array}{l}\text { Treatment } \\
\text { period }(\mathrm{h})\end{array}$} & \multicolumn{3}{|c|}{ Cultivar Aroma $^{z}$} & \multicolumn{3}{|c|}{ Cultivar Ingrid Marie ${ }^{z}$} \\
\hline & & $\begin{array}{l}\text { Penicillium } \\
\text { expansum }\end{array}$ & $\begin{array}{c}\text { Pezicula } \\
\text { malicorticis }\end{array}$ & $\begin{array}{l}\text { Colletotrichum } \\
\text { gloeosporioides }\end{array}$ & $\begin{array}{c}\text { Penicillium } \\
\text { expansum }\end{array}$ & $\begin{array}{c}\text { Pezicula } \\
\text { malicorticis }\end{array}$ & $\begin{array}{l}\text { Colletotrichum } \\
\text { gloeosporioides }\end{array}$ \\
\hline \multirow{4}{*}{ Air: $21.0 \mathrm{kPa} \mathrm{O}{ }_{2}+0.03 \mathrm{kPa} \mathrm{CO}$} & (0) Control & $8.2 \mathrm{a}^{\mathrm{y}}$ & $17.1 \mathrm{a}$ & $4.8 \mathrm{a}$ & $14.0 \mathrm{a}$ & $13.0 \mathrm{a}$ & $4.0 \mathrm{a}$ \\
\hline & 48 & $4.2 \mathrm{bc}$ & $7.5 \mathrm{bc}$ & $2.2 \mathrm{~cd}$ & $6.6 \mathrm{c}$ & $5.1 \mathrm{e}$ & $2.0 \mathrm{c}$ \\
\hline & 72 & $4.5 \mathrm{~b}$ & $8.4 \mathrm{~b}$ & $2.7 \mathrm{bc}$ & $7.2 \mathrm{bc}$ & $6.0 \mathrm{c}$ & $2.3 \mathrm{bc}$ \\
\hline & 96 & $4.5 \mathrm{~b}$ & $7.7 \mathrm{bc}$ & $3.0 \mathrm{~b}$ & $8.3 \mathrm{~b}$ & $6.0 \mathrm{c}$ & $2.4 \mathrm{bc}$ \\
\hline \multirow[t]{3}{*}{ CA: $2.0 \mathrm{kPa} \mathrm{O}{ }_{2}+2.0 \mathrm{kPaCO}$} & (0) & $3.8 \mathrm{bc}$ & $8.1 \mathrm{~b}$ & $2.4 \mathrm{bc}$ & $8.4 \mathrm{~b}$ & $10.9 \mathrm{~b}$ & $2.0 \mathrm{c}$ \\
\hline & 72 & $2.2 \mathrm{~d}$ & $4.5 \mathrm{de}$ & $1.6 \mathrm{de}$ & $3.5 \mathrm{e}$ & $5.4 \mathrm{de}$ & $1.0 \mathrm{~d}$ \\
\hline & 96 & $3.2 \mathrm{c}$ & $4.9 \mathrm{de}$ & $1.6 \mathrm{de}$ & $5.4 \mathrm{~d}$ & $5.9 \mathrm{~cd}$ & $1.2 \mathrm{~d}$ \\
\hline
\end{tabular}

${ }^{\mathrm{z}}$ Mean squares from GLM analyses of lesion area showed no significant interactions exposure periods-seasons. Values are transformed means of three seasons (2003-2005) and three replicates of 540 inoculation areas.

${ }^{y}$ Means followed by different letters within the same columns for either pathogen are significantly different at least significant difference $=0.05$.

skin damage, particularly in stored cv. Ingrid Marie, possibly because of stomata destroyed at higher heat becoming sites of subsequent decay (data not shown). The positive effects of combined heat treatment and CA storage on bruising, bull's eye rots (Pz. malicorticis), and bitter rot (C. gloeosporioides) reported here are novel information. The method improved the eradicative effect and increased residual activity of heating and CA storage, because it caused significantly lower decay than heated apples stored in air or than nonheated apple stored in CA.

Apple defense systems against fungi, which comprise either complex constitutive or nonconstitutive interactions, can be improved by heating (Ben-Yehoshua et al., 1998). Heat treatment was previously found to inhibit respiration rate and ethylene pro- duction (Lurie et al., 1995). Our study showed that heat treatment caused an acceleration of $\mathrm{CO}_{2}$ production in the first week of storage, which recovered during the subsequent storage period, but had no such effect on ethylene production. From the fifth week until the end of the storage, both parameters remained lower in the heat-treated fruits than in the nonheated. Thus, heat treatment delayed ripening and softening and thereby improved apple resistance to fungal infection during storage (Janisiewicz et al., 2003; Saftner et al., 2003). Heat treatment may also enhance host resistance to fungal attack by physiological or structural changes in the fruit surface. Fungal spores and latent infections occur either in the fruit surface or in the few cell layers under the apple peel. Cracks, wounds, and other breaks in the fruit surface are therefore the most important vents for hyphal penetration (Porat et al., 2000; Schirra et al., 2000). Nonheated fruit have an interconnected network of numerous deep surface cracks in their epicuticular wax, whereas the epicuticular wax of heat-treated fruit has no such network (Lurie et al., 1996; Roy et al., 1994). In this study, we observed significant changes in epicuticular wax resulting from heat treatment with melted wax filling microcracks; covering germinated spores, conidia, and hyphae; and preventing inoculation. Differing cultivar responses to heating may be the result of variations in skin wax amount and structure. Apples with heavier and hardened epicuticular wax layers, containing few or no cracks, showed better resistance to pathogen attack, whereas apples with a clumpy wax layer showed better response to heat treatment. Nail-like wax 
crystals needed higher temperatures to melt and protect against decay. Heat treatment melted wax platelets into cracks and did not recrystallize them, as reported previously (Roy et al., 1994).

From the provided data, it could be concluded that heat treatment at $40{ }^{\circ} \mathrm{C}$ and exposure period for $24 \mathrm{~h}$ in combination with CA storage is a promising strategy for increasing resistance to bruising and fungal decay in both cv. Aroma and cv. Ingrid Marie. This method provided acceptable protection against bull's eye rot (Pz. malicorticis) and bitter rot (C. gloeosporioides) and shorted the exposure period.

\section{Literature Cited}

Abbott, J.A., J.D. Klein, T.A. Campbell, W.S. Conway, and C.E. Sams. 2000. Sensory and firmness measurements of calcium- and heat treated apples. J. Texture Stud. 31:109-121.

Barkai-Golan, R. and D.J. Philips. 1991. Postharvest heat treatment of fresh fruits and vegetables for decay control. Plant Dis. 75:1085-1089.

Ben-Shalom, N., J. Hanzon, R. Pinto, and S. Lurie. 1996. Cell wall changes and partial prevention of fruit softening in prestorage heat treated 'Anna' apples. J. Sci. Food Agr. 72:231-234.

Ben-Yehoshua, S., V. Rodov, and J. Peretz. 1998. Constitutive and induced resistance of citrus fruit against pathogens, p. 78-92. In: Johnson, G.I., E. Highly, and D.C. Joyce (eds.). Disease resistance in fruit. ACIAR Proc. No. 80, Canberra, Australia.

Chen, P. and Z. Sun. 1981. Impact parameters in relation to bruise injury in apples. Amer. Soc. Agr. Eng. Pap. 81:3041

Conway, W.S., B. Leverentz, W.J. Janisiewicz, A.B. Blodgett, R.A. Saftner, and M.J. Camp. 2004. Integrating heat treatment, biocontrol and sodium bicarbonate to reduce postharvest decay of apple caused by Colletotrichum acutatum and Penecillium expansum. Postharvest Biol. Technol. 34:11-20.

Conway, W.S., C.E. Sams, C.Y. Wang, and J.A. Abbott. 1994. Additive effects of postharvest calcium and heat treatment on reducing decay and maintaining quality in apples. J. Amer. Soc. Hort. Sci. 119:49-53.

Ericsson, N.A. 1989. Possibilities for reduction of mechanical damages during distribution of apples. Obst und Gemüse DGQ XXIV:126-136.

Ericsson, N.A. and I.I. Tahir. 1996. Studies on apple bruising. I. Estimation of incidence and susceptibility differences in the bruising of three apple cultivars. Acta Agr. Scand. Sect. B. Soil and Plant Sci. 46:209-213.
Fallik, E., S. Grinberg, M. Gambourg, J.D. Klein, and S. Lurie. 1995. Prestorage heat treatment reduces pathogenicity of Penicillium expansum in apple fruit. Plant Pathol. 45:92-97.

Ferguson, B., S. Ben-Yehoshua, E.J. Mitcham, R.E. McDonald, and S. Lurie. 2000. Postharvest heat treatments: Introduction and workshop summary. Postharvest Biol. Technol. 21:1-6.

Funt, R.C., E.A. Cameron, and N.H. Banks. 1999. The effect of apple fruit bruising on total returns. Research Circular-Ohio Agricultural Research and Development Center 299:55-61.

Grajkowski, J., I. Ochmian, P. Chelpinski, and G. Mikiciuk. 2004. Evaluation of susceptibility to mechanical damage in several cultivars of apple trees. Folia Universitatis Agriculturae Stetinensis. Agricultura 93:113-117.

Haffner, K.E. 1993. Storage trial of 'Aroma' apples at the Agricultural University of Norway. Acta Hort. 326:305-313.

Janisiewicz, J.W., B. Leverentz, S.W. Conway, R.A. Saftner, A.N. Reed, and M.J. Camp. 2003. Control of bitter rot and blue mold of apples by integrating heat and antagonist treatments on 1MCP treated fruit stored under controlled atmosphere conditions. Postharvest Biol. Technol. 29:129-143.

Klein, J.D. and S. Lurie. 1992. Heat treatments for improved postharvest quality of horticultural crops. HortTechnology 2:316-320.

Klein, J.D., S. Lurie, and R. Ben Arie. 1990 Quality and cell wall components of 'Anna' and 'Granny Smith' apples treated with heat, calcium, and ethylene. J. Amer. Soc. Hort. Sci. 115:954-958.

Leverentz, B., W.S. Conway, W.J. Janisiewicz, R.A. Saftner, and M.J. Camp. 2003. Effect of combining MCP treatment, heat treatment, and biocontrol on the reduction of postharvest decay of 'Golden Delicious' apples. Postharvest Biol. Technol. 27:221-233.

Leverentz, B., W.J. Janisiewicz, W.S. Conway, R.A. Saftner, Y. Fuchs, and M.J. Camp. 2000. Combining yeasts or a bacterial biocontrol agent and heat treatment to reduce postharvest decay of 'Gala' apples. Postharvest Biol. Technol. 12:87-94

Lurie, S. 1998. Postharvest heat treatments. Postharvest Biol. Technol. 14:257-269.

Lurie, S., A. Handros, E. Fallik, and R. Shapira 1996. Reversible inhibition of tomato fruit gene expression at high temperature. Plant Physiol. 110:1207-1214.

Lurie, S., S. Othman, and A. Borochov. 1995. Effects of heat treatment on plasma membrane of apple fruit. Postharv. Biol. Physiol. 5:29-38.

McGuire, R. 1992. Reporting of objective colour measurements. HortScience 27:1254-1255.
Miller, W.R., D. Chun, L.A. Risse, T.T. Hatton, and R.T. Hinch. 1990. Conditioning of Florida grapefruit to reduce peel stress during low temperature storage. HortScience 25:209-211.

Porat, R., D. Pavoncello, J. Peretz, B. Weiss, A. Daus, L. Cohen, S. Ben-Yehoshua, E. Fallik, S. Droby, and S. Lurie. 2000. Induction of resistance to Penicillium digitatum and chilling injury in 'Star Ruby' grapefruit by a short hot water rinse and brushing treatment. J. Hort. Sci. Biotechnol. 75:428-432.

Rappel, L.M., A.W. Cooke, K.K. Jacobi, and I.A. Wells. 1991. Heat treatment for postharvest disease control in mangoes. Acta Hort. 291:362-371.

Rein, A. 1996. Apple storage disorders (original title in Swedish: Skador på äpplen vid Inlagring). Swedish Board of Agr. Agro. Info 3810 Gvarv, www.sjv.se. 1-16.

Roy, S., W.S. Conway, A.E. Watada, C.E. Sams, E.F. Erbe, and W.P. Wergin. 1994. Heat treatment affects epicuticular wax structure and postharvest calcium uptake in 'Golden Delicious' apples. HortScience 29:1056-1058.

Saftner, R.A., J.A. Abbott, W.S. Conway, and C.L. Barden. 2003. Effects of 1-Methylcyclopropene and heat treatments on ripening and postharvest decay in 'Golden Delicious' apples. J. Amer. Soc. Hort. Sci. 128:120-127.

Schirra, M., G. D'Hallewin, S. Ben-Yehoshua, and E. Fallik. 2000. Host-pathogen interactions modulated by heat treatment. Postharvest Biol. Technol. 21:71-85.

Sholberg, P., P. Haag, R. Hocking, and K. Bedford. 2000. The use of vinegar vapor to reduce postharvest decay of harvested fruit. HortScience 35:898-903.

Spadaro, D., A. Garibaldi, and M.L. Gullino. 2004 Control of Penecillium expansum and Botrytis cinerea on apple combining a biocontrol agent with hot water dipping and acibenzolar-Smethyl, baking soda, or ethanol application. Postharvest Biol. Technol. 33:141-151.

Tahir, I., E. Johansson, and M.E. Olsson. 2005. Groundcover materials improve quality and storability of 'Aroma' apples. HortScience 40:1416-1420.

Tahir, I., E. Johansson, and M.E. Olsson. 2007. Improvement of quality and storability of apple cv. 'Aroma' by adjustment of some pre-harvest conditions. Scientia Hort. 112:164-171.

Tahir, I.I. 2006. Control of pre- and postharvest factors to improve apple quality and storability. PhD Diss., Plant Breeding and Biotechnology Dept., Swedish University of Agricultural Sciences, Alnarp, Sweden.

Zhang, W. 1994. Apple impact bruise analysis. PhD Diss., Biological Systems Engineering Dept., College of Engineering and Architecture, Washington State University, Pullman, WA. 